\title{
462 粘弾性ダンパーによる電車線柱の減衰性能向上
}

Improvement of Damping Performance of Electric Railway Pole with Visco-elastic Damper

$\begin{array}{rllll}\text { O正 } & \text { 網干 光雄 (鉄道総研) } & \text { 正 } & \text { 常本 } & \text { 瑞樹 (鉄道総研) } \\ \text { 正 } & \text { 砂子田勝昭 (秋田大学) } & \text { 正 } & \text { 松岡 } & \text { 太一 (秋田大学) } \\ & \text { 五十幡直文 (三和テッキ) } & & \text { 柴田 } & \text { 和彦（三和テッキ) }\end{array}$

Mitsuo ABOSHI, Mizuki TSUNEMOTO, Railway Technical Research Institute, 2-8-38 Hikari-cho, Kokubunji-shi, Tokyo Katsuaki SUNAKODA, Taichi MATSUOKA, Akita University, 1-1 Tegata Gakuen-machi, Akita-shi, Akita Naobumi IKAHATA, Kazuhiko SHIBATA, Sanwa Tekki Co., 2703 NakaOkamoto-cho, Utsunomiya-shi, Tochigi

A damping device for electric-railway pole has been invented in order to reduce the vibration caused by an earthquake or passing train. The authors conducted theoretical analyses of pole response equipped with the damping device and vibration test of real scale pole. The result of theoretical analyses has been found to be almost identical to the result of vibration test. Moreover, as the result of vibration test, damping effect of the device has been verified.

Key words: electric railway, current collection, pole, damping, visco-elastic damper, loss factor

電気鉄道の架線を支持する電柱について, その耐震性向上 及び架線の振動抑制を目的に, 電柱に減衰機能を付加して共 振周波数付近での振動を抑制する手法を考案した. 本論文で は, 梁モデルによる電柱制振特性を解析するとともに, 粘弹 性ダンパー（制振器）を試作して，実スケール電柱を用いた 実装加振試験を行なってその効果を確認した結果について 報告する.

図A1は，電柱及び制振器の解析モデルである。図A2に，地 際を加振した際の先端応答倍率の例を示す. 制振器の減衰係 数を増加させると片端固定梁の固有振動数付近の応答倍率 は低減するが, さらに大きくすると制振器より上部の固有振 動数に遷移して応答倍率が増加する.したがって減衰係数の 最適值が存在する. 最適減衰值は次式で示される.

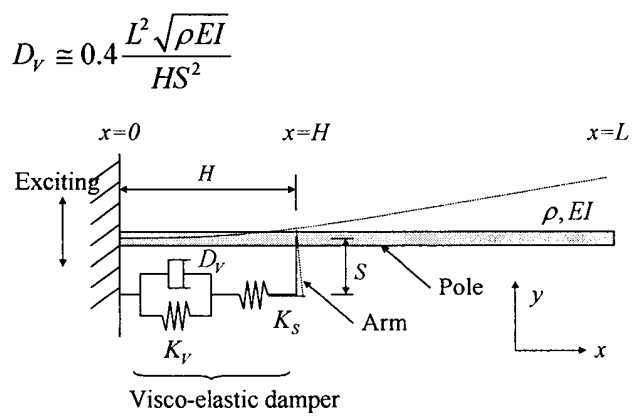

Fig.Al Analysis model of pole and visco-elastic damper

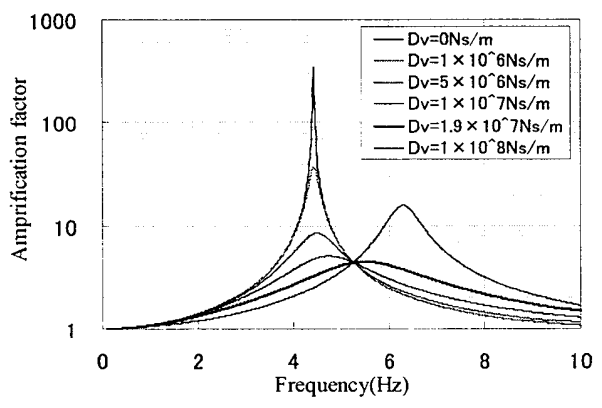

Fig.A2 Amplification factor of pole-top displacement
図A3に粘弾性体を用いた制振器の構造と外観を示す。制振 器は粘弾性体を鋼板で挟んで積層した構造で, 電柱地際部に 取り付けて電柱たわみ時の微小なせん断変形による減衰を 利用する制振方法である。

鋼管柱での実装加振試験の結果, 電柱の損失係数が約 10 倍 増加すること，制振体を直交して取り付けることにより全方 向に対して制振効果があることを確認した（図A4）。また加 振台に扔いて兵庫県南部地震波で加振した結果, コンクリー ト柱の地際曲げひずみ（モーメント）が約 $1 / 2$ に低減するこ とを確認した.
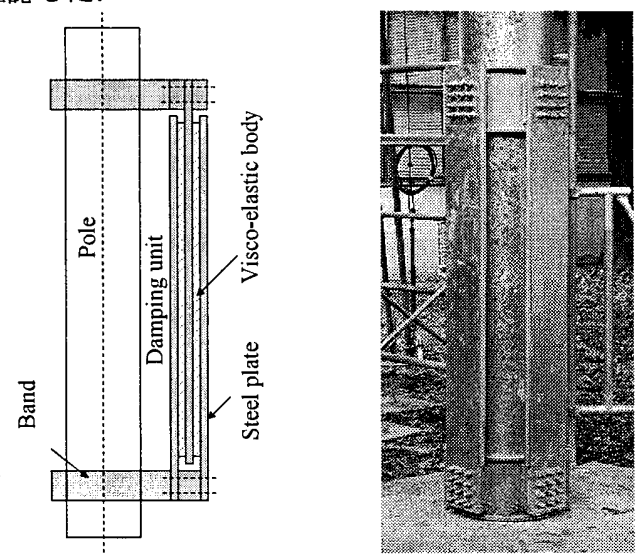

Fig.A3 Structure of damping device

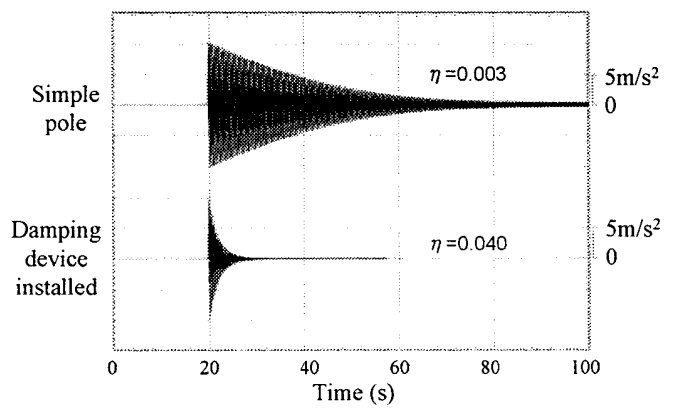

Fig.A4 Comparison of pole-top acceleration waveform

日本機械学会〔No.09-23〕Dynamics and Design Conference 2009 CD-ROM 論文集〔2009.8.3-8,札幌〕 


\section{1.はじめに}

電気鉄道の架線を支持する電柱は，地震時において曲げ 振動が発生し, 特に, 鉄道高架橋と電柱の固有振動数が一 致する場合に共振現象により倒壊する恐れがある1).また， 高架橋と電柱・架線の各固有振動数が一致したため過大な 架線振動が励起され，走行中のパンタグラフの割り込み・

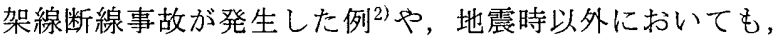
列車通過時の電柱振動により架線に過大な振動が発生し， 架線金具の疲労破損等に至る例もある ${ }^{3)}$.

そこで電柱の耐震性能向上及び架線の振動抑制を目的 に，電柱に減衰機能を付加して共振周波数付近での振動を 抑制する手法を考案した，検討にあたっては，鉄道現場の 施工性, 保全性等を考慮して, 現用の電柱に減衰を付加す る方法で, 電柱単独で施工できることを前提とした．また， 軽量であり施工性に優れていること, 微細な調整を要しな いこと，安価で耐候性に優れていることなども考慮した。 そこで, 微小変位でも減衰効果を得やすい粘弾性体を用い て，これを鋼板で挟んで積層した構造にして電柱下部に取 り付ける方法とした。

本論文では，梁モデルによる電柱制振特性を解析すると ともに, 粘弾性ダンパー（以下，「制振器」という）を試 作して実スケール電柱を用いた実装加振試験を行ってその 効果を確認した結果について報告する。

\section{2. 梁モデルによる応答解析}

\section{1 運動方程式}

ここでは，電柱を片端固定の梁として考える，梁の線密 度，曲げ剛性をそれぞれ $\rho, E I$ とすれば，梁の運動方程式は 式(1)で表される.

$$
\rho \frac{\partial^{2} y}{\partial t^{2}}+E I \frac{\partial^{4} y}{\partial x^{4}}=0
$$

この解を $y=A \exp (i \omega t+k x)$ とおいて, 式(1)に代入すると,

$$
-\rho \omega^{2}+E I k^{4}=0
$$

の特性方程式が得られる。ここで， $\omega, k, i$ はそれぞれ振動 角周波数, 波数, 虚数単位で,

$$
\begin{aligned}
& k_{1}=\alpha, k_{2}=-\alpha, k_{3}=i \alpha, k_{4}=-i \alpha \\
& \alpha=\left(\frac{\rho}{E I}\right)^{1 / 4} \omega^{1 / 2}
\end{aligned}
$$

とすれば，梁のたわみの一般解は次式で表される.

$$
y=\left(\sum_{n=1}^{4} A_{n} \exp k_{n} x\right) \exp i \omega t
$$

図 1 に示すように, 電柱の長さを $L$, 地際からの高さ $H に$ 長さ $S$ の腕金を直角に出し，地際との間に制振器を挿入す る. 制振器は, 粘弾性体自体の減衰係数 $D_{V}$ (速度比例型の 粘性減衰）と剛性 $K_{r}$ が並列に接続され，さらに鋼板および 電柱バンド（腕金含む）の縦剛性 $K_{S}$ が直列に配置されるも のとしてモデル化する. $x=0$ (地際) において $y=A_{b}$ expica 強制変位を与えたとき, 電柱変位 $y_{a}, y_{b}$ を式 (5) で表す.

$$
\begin{aligned}
& y_{a}=\left(\sum_{n=1}^{4} A_{a n} \exp k_{n} x\right) \exp i \omega t \quad(0 \leq x \leq H) \\
& y_{b}=\left(\sum_{n=1}^{4} A_{b n} \exp k_{n} x\right) \exp i \omega t \quad(H<x \leq L)
\end{aligned}
$$

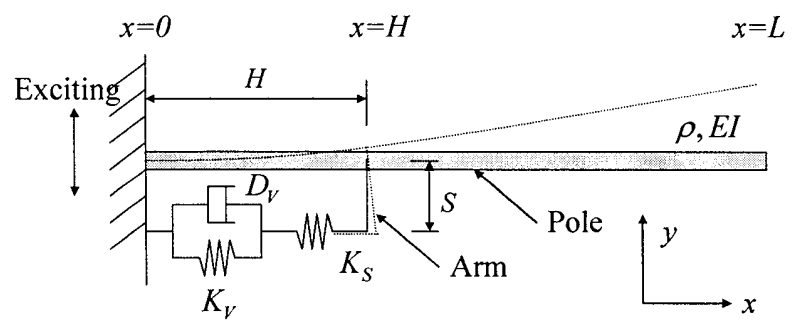

Visco-elastic damper

Fig. 1 Analysis model of pole and visco-elastic damper

このとき,(1) $x=0$ における変位が強制変位と一致, (2) $x=0$ において傾斜が0 $(\partial y / \partial x=0) ，(3) x=L$ においてモーメン トが $0\left(\partial^{2} y / \partial x^{2}=0\right) ，(4) x=L$ においてせん断力が 0 $\left(\partial^{3} y / \partial x^{3}=0\right),(5) x=H$ において変位が連続，(6) $x=H$ に おいて傾斜が連続，(7) $x=H$ においてせん断力が連続とい う境界条件が成り立つ。さらに(8) $x=H$ において, 制振器 の作用力によるモーメントMexpiat が加わるが,

$$
\begin{aligned}
M \text { expi } i t & =S \cdot\left[-Z \cdot \frac{d}{d t}\left\{\left.\frac{\partial y}{\partial x}\right|_{x=H} \cdot S\right\}\right] \\
& =-S^{2} \cdot Z \cdot i \omega\left(\sum_{n=1}^{4} k_{n} A_{a n} \exp k_{n} H\right) \exp i \omega t
\end{aligned}
$$

であるから，

$$
M=-S^{2} Z \cdot i \omega\left(\sum_{n=1}^{4} k_{n} A_{a n} \exp k_{n} H\right)
$$

である.ただし, $Z$ は制振器の機械インピーダンスであり，

$$
Z=\frac{\frac{K_{S}}{i \omega}\left(D_{V}+\frac{K_{V}}{i \omega}\right)}{D+\frac{\left(K_{V}+K_{S}\right)}{i \omega}}=\frac{K_{S}\left(K_{V}+i \omega D_{V}\right)}{i \omega\left\{\left(K_{V}+K_{S}\right)+i \omega D_{V}\right\}}
$$

である。

以上の境界条件を表す 8 元連立 1 次方程式を解くことに より各係数 $A_{a 1} \sim A_{a 4}, A_{b 1} \sim A_{b 4}$ を代数的に求めることができる が, これらの係数を数式で表現すると非常に複雑になるの で, ここでは数值計算により求める.

\section{2 応答倍率等}

地際加振時における電柱先端変位の応答倍率（地際単位 加振振幅あたりの電柱先端振幅）は，

$$
\beta_{1}=\frac{\sum_{n=1}^{4} A_{b n} \exp k_{n} L}{A_{0}}
$$

で表される.また制振器間の軸方向変位は, 制振器上部の 上下変位（図 1 の $x$ 方向）は,

$$
\left.\frac{\partial y_{a}}{\partial x}\right|_{x=H} \cdot S
$$

であるから, 制振器間変位の応答倍率（地際単位加振振幅 あたりの制振器間変位振幅）は，

$$
\beta_{2}=\frac{S\left(\sum_{n=1}^{4} k_{n} A_{a n} \exp k_{n} H\right)}{A_{0}}
$$


で表される. 地際加振時において制振器に作用する力 $F($ 制 振器上部腕金に上向きに作用する場合を正とする）は，

$$
F=-Z \cdot \frac{d}{d t}\left(\left.\frac{\partial y_{a}}{\partial x}\right|_{x=H} \cdot S\right)
$$

であるから, 制振器作用力の応答倍率（地際単位加振振幅 あたりの制振器に作用する力振幅）は，

$$
\beta_{3}=\frac{-S \cdot Z \cdot i \omega\left(\sum_{n=1}^{4} k_{n} A_{a n} \exp k_{n} H\right)}{A_{0}}
$$

で表される，電柱地際曲げモーメントは，

$$
M \exp i \omega t=-\left.E I \frac{\partial^{2} y_{a}}{\partial x^{2}}\right|_{x=0}
$$

であるから，地際曲げモーメントの応答倍率（地際単位加 振振幅あたりの地際曲げモーメント振幅）は,

$$
\beta_{4}=\frac{-E I\left(\sum_{n=1}^{4} k_{n}^{2} A_{a n}\right)}{A_{0}}
$$

で表される。

図 2 に，例として，鋼管柱（ $\phi 355.6 \mathrm{~mm}$ ，厚さ6.4mm，地 際上長さ $\left.L=9 \mathrm{~m}, \rho=55.1 \mathrm{~kg} / \mathrm{m}, E I=2.25 \times 10^{7} \mathrm{Nm}^{2}\right)$ を想定し, 制振器の取付高さ $H=1.5 \mathrm{~m}$, 腕金長さ $S=0.2 \mathrm{~m}$ の条件におい て, 制振器の減衰倸数を変化させた場合の先端応答倍率を 比較して示す。ただし, 簡単のため $K_{V}=0, K_{S}=\infty$ としてい る.また電柱自体の減衰については，その縦弾性係数を $E(1+i \eta)$ として複素数で表現する. $\eta$ は損失係数で, 実験 結果 ${ }^{4)}$ から0.004としている.

この場合， $4.4 \mathrm{~Hz}$ 付近に共振周波数があるが，これは

$$
f=\frac{1}{2 \pi}\left(\frac{1.875}{L}\right)^{2}\left(\frac{E I}{\rho}\right)^{1 / 2}
$$

で表わされる片端固定の梁の 1 次固有振動数に相当する. また制振器の減衰係数 $D_{V}$ を增大させていくと共振周波数 付近の応答倍率は低下するが，ある限度を超えると共振周 波数が高周波側へ遷移し応答倍率が増加する。このときの 遷移した共振周波数は, 制振器取付高さより先端側の部分 のみの固有振動数，すなわちこの場合，式 (12)において $L=7.5 \mathrm{~m}$ とした場合の固有振動数 $6.4 \mathrm{~Hz}$ に一致する。これは 制振器取付高さ位置の変位が, 制振器によってほぼ完全に 拘束されるためと考えられる。したがってこの制振器には

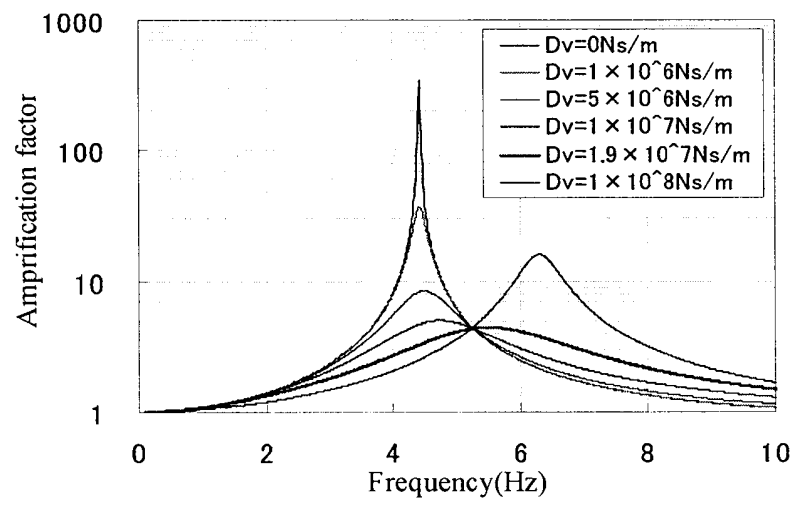

Fig.2 Example of amplification factor of pole-top displacement
最適減衰值が存在することがわかる.

\section{3 最適減衰}

制振器の最適減衰值を得るには, 式(8)を使って, $\partial \beta_{1} / \partial D_{V}=0$ となる $D_{V}$ を求めればよいが, 見通しの良い式で 表わすことは困難である，そこで以下に示すように，先端 加振時の応答を考えて, 制振器の隇衰要素のみを考慮し $\left(K_{V}=0, K_{S}=\infty\right)$, 近似的に簡易式を求めることとする.

図 3 に示すように, 先端 $(x=L)$ において加振力 Pexpiat, 制 振器取付点 $(x=H)$ においてモーメントMexpia が作用すると 考える. $\omega$ が片端固定の 1 次固有振動数より十分低い場合 は，各部のたわみ変位は静的たわみ変位とほぼ同じと考え ると, 式(13)で示される.

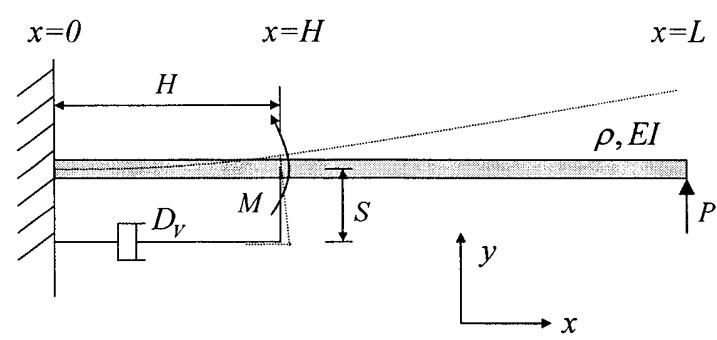

Fig.3 Analysis model for optimum damping

$$
\begin{aligned}
& y_{a}=\frac{3 M x^{2}+3 P L x^{2}-P x^{3}}{6 E I} \exp i \omega t \quad(0 \leq x \leq H) \\
& y_{b}=\frac{3 P L x^{2}-P x^{3}+6 M H x-3 M H^{2}}{6 E I} \operatorname{expi\omega t}(H<x \leq L)
\end{aligned}
$$

一方，制振器の作用力によるモーメントは，

$$
\begin{aligned}
M \exp i \omega t & =-D_{V} \frac{d}{d t}\left(\left.\frac{d y_{a}}{d x}\right|_{x=H} \cdot S\right) S \\
& =-i \omega D_{V} \frac{H S^{2}}{2 E I}(2 M+2 P L-P H) \exp i \omega t
\end{aligned}
$$

であるから，

$$
M=-\frac{i \omega D_{V} \frac{H S^{2}}{2 E I} P(2 L-H)}{1+i \omega D_{V} \frac{H S^{2}}{E I}}
$$

と求まり,これを使って先端の変位は， $\gamma=H / L$ とすれば

$$
\left.y_{b}\right|_{x=L}=\frac{P L^{3}}{3 E I}\left\{1-\frac{i \omega D_{V} \frac{H S^{2}}{E I} 3 \gamma\left(1-\frac{\gamma}{2}\right)^{2}}{1+i \omega D_{V} \frac{H S^{2}}{E I}}\right\} \exp i \omega t \ldots
$$

で表すことができる.\{\}内第 1 項は先端作用力Pによる静 的変位に相当し，第 2 項は制振器を取り付けることによる 忘答変位分に相当する.この式は固有振動数より十分低い 場合の変位であるが，固有振動数付近においてもたわみ曲 線の形状がこれとほぼ同様だと仮定すれば，\{\}内の関係を ほぼ維持するものと考えられる。ささらに最適減衰の状態で は, 制振器を取り付けることによる応答変位が先端加振力 単独による変位とほぼ同等程度になっていると考えられる ので，式(15)の\{\}内を0とおいた条件は， 


$$
i \omega D_{V} \frac{H S^{2}}{E I}\left\{1-3 \gamma\left(1-\frac{\gamma}{2}\right)^{2}\right\} \approx-1
$$

となる。両辺は位相が異なるので,ここでは絶対値がほぼ 一致する条件（擬似等価）を考えると，

$$
D_{v} \cong \frac{1}{\omega \frac{H S^{2}}{E I}\left\{1-3 \gamma\left(1-\frac{\gamma}{2}\right)^{2}\right\}}
$$

となる。一方, 最適減衰状態の周波数は, 図 2 を参考に, 長さ $L$ の場合の态答倍率曲線と, 長さ $L-H$ の場合の忘答倍 率曲線の交点に相当すると考えられる．そこで，片端固定 梁の忘答倍率を 1 質点のばね質点系モデルで置き換えて, それぞれ固有角周波数を $\omega_{1}, \omega_{2}$ として，これらの応答倍率の 位相を考慮して負符号を付けて等值とおくと,

$$
\frac{1}{1-\left(\omega / \omega_{1}\right)^{2}}=-\frac{1}{1-\left(\omega / \omega_{2}\right)^{2}}
$$

であるから，最適減衰状態の角周波数を，

$$
\omega=\sqrt{\frac{2}{1 / \omega_{1}^{2}+1 / \omega_{2}^{2}}}=\left(\frac{1.875}{L}\right)^{2} \sqrt{\frac{E I}{\rho}} \sqrt{\frac{2}{1+(1-\gamma)^{4}}}
$$

と近似する。これを式(16)に代入して整理すると，

$$
D_{V} \cong \frac{1}{1.875^{2}} \cdot \frac{L^{2} \sqrt{\rho E I}}{H S^{2}} \cdot \frac{\sqrt{\frac{1+(1-\gamma)^{4}}{2}}}{\left\{1-3 \gamma\left(1-\frac{\gamma}{2}\right)^{2}\right\}}
$$

となる．本検討における制振器の大きさは， $y=0.1 \sim 0.2$ 程度を考えているので，上式最終項は $1.2 \sim 1.6$ 程度とな る.したがってその中間の值を採用して係数をまとめると， 最適減衰值は以下の簡易式で表わすことができる.

$$
D_{V} \cong 0.4 \frac{L^{2} \sqrt{\rho E I}}{H S^{2}} \text { ，あるいは }=0.4 \frac{L \sqrt{\rho E I}}{\gamma S^{2}}, \gamma=\frac{H}{L}
$$

$\sqrt{\rho E I}$ は, 無限長梁の機械インピーダンスに比例する項で あるので, 制振器の最適減衰值は, 電柱の機械インピーダ ンスならびに長さの二乗の比例し, 制振器の長さならびに 腕金長さの二乗に反比例することがわかる.

図 2 中に示した $D_{V}=1.9 \times 10^{7} \mathrm{Ns} / \mathrm{m}$ の応答倍率曲線は, 当該 電柱条件に基づいて式(20)の簡易式から求めた最適減衰値 であり，応答倍率の最も小さい最適減衰の状態に近いこと がわかる。

\section{3. 制振器の構造と電柱制振特性}

図 4 に，粘弾性体を用いた制振器の構造概要図を示す.制 振体は, 微小変形でも減衰効果が得られる粘弾性体を鋼板で 挟んだ構造とし，この制振体を電柱バンドで電柱に固定す

Band

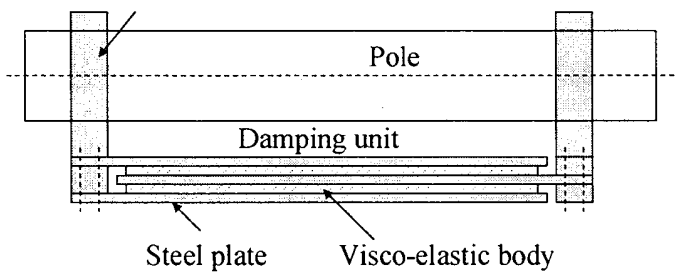

Fig.4 Structure of damping device
る. 電柱の曲げ変形が生じた際に制振体が伸縮変形し, 粘弾 性体がせん断変形することにより減衰効果を得る.

図 1 の制振器モデルにおいて, 制振器両端の速度差を $v$ と すると, 減衰要素雨端の速度差 $v_{V}$ は,

$$
v_{V}=\frac{1}{1+\frac{K_{V}}{K_{S}}+D_{V} \frac{i \omega}{K_{S}}} v
$$

である．効果的な制振特性を得るためには，電柱の曲げ振動 に伴う減衰要素両端の速度差ができるだけ大きいことが望 ましい，すなわち，粘弾性体の剛性 $K_{V}$ をできるだけ小さく， 鋼板及び電柱バンドの剛性 $K_{S}$ をできるだけ大きくしておく ことが望ましい。

ここでは制振器の特性として, 表 1 に示すような当面の目 標値を設定した. 粘弾性体の減衰係数及び剛性は, 材料及び 使用温度で異なる. 粘弾性体としては, 比較的減衰係数が大

\begin{tabular}{|c|c|c|c|}
\hline Temperature $\left({ }^{\circ} \mathrm{C}\right)$ & $D_{V}(\mathrm{Ns} / \mathrm{m})$ & $K_{V}(\mathrm{~N} / \mathrm{m})$ & $K_{S}(\mathrm{~N} / \mathrm{m})$ \\
\hline 10 & $1.2 \times 10^{7}$ & $2 \times 10^{8}$ & \multirow{3}{*}{$2 \times 10^{8}$} \\
\hline 20 & $4 \times 10^{6}$ & $1.2 \times 10^{8}$ & \\
\hline 30 & $2 \times 10^{6}$ & $6 \times 10^{7}$ & \\
\hline
\end{tabular}
きく剛性の小さい特性のアクリル系粘弾性体（３Ｍ社製 ISD111）を選択した。減衰係数については, 式(20)から試算 した最適減衰值を目標としたが，施工上に扮ける実用的な大 きさ, 重量, 構造等を考慮して, これよりも小さい値となっ ている.

Table 1 Designed characteristics of damping device $(4.4 \mathrm{~Hz})$

図 $5 \sim 8$ に, 上記特性値を用いた場合の忘答倍率等の周 波数特性を示す.この場合の電柱として, 鋼管柱 $(\phi 355.6 \mathrm{~mm}$, 厚さ6. $4 \mathrm{~mm}$, 地際上長さ $9 \mathrm{~m}$ ) を対象としている. 電柱制振器 の長さは $1.5 \mathrm{~m}$, 電柱バンドの腕金の長さ（電柱中心からの 距離）は0. $2 \mathrm{~m}$ とする. 粘弾性体の減衰係数, 剛性は周波数 により変化するが，ここでは一定として計算している。ま た鋼管柱自体の損失係数は, $1 / 2$ スタールモデルでの加振試 験結果 ${ }^{4)}$ から $\eta=0.004$ とする.

図 5 は先端応答倍率を示すが, 制振器がない場合400倍程

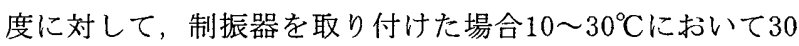
〜40倍程度とおおむね一定であり, 制振器なしに比べてほ ぼ $1 / 10$ に減少する. 温度 $10^{\circ} \mathrm{C}$ と $30^{\circ} \mathrm{C}$ とでは粘弾性体の減衰 倸数に 1 桁近い差があるにも倸わらず，応答倍率はほぼ同

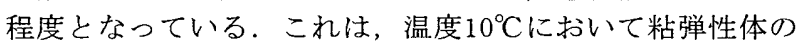
剛性が増加し, その結果, 鋼板および電柱バンドの剛性と ほぼ同等となり制振効果が低減されることによるものと考 えられる. 制振効果の低減は望ましいことではないが，温 度差による制振効果の差異が少ないという意味では好都合 である。なお制振器を取り付けることにより, その剛性付 加により固有振動数が若干増加する.

図 6 は制振器間の軸方向変位の応答倍率を示すが, 地際の 加振振幅を $1 \mathrm{~mm}$ と仮定すると, 最大で $0.3 \mathrm{~mm}$ 程度の変位が生 じることになる.このうちの 50〜 70\%程度が粘弾性体のせん 断変形として加わることになる.

図 7 は制振器間の作用力の忘答倍率を示すが, 地際の加振 振幅を $1 \mathrm{~mm}$ と仮定すると，最大で $3 \times 10^{4} \mathrm{~N}$ 程度の力が作用す ることになる。

図 8 は地際曲げモーメントの応答倍率を示すが, 地際の加 振振幅を $1 \mathrm{~mm}$ と仮定すると, 制振器がない場合には最大で 


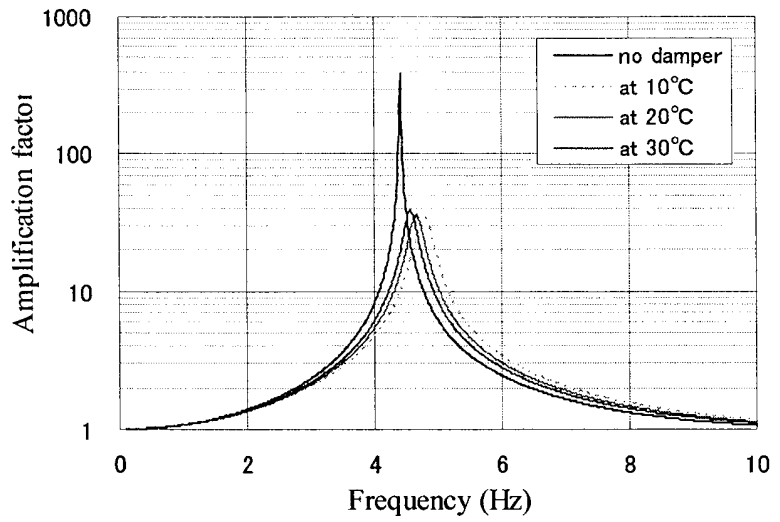

Fig.5 Amplification factor of pole-top displacement

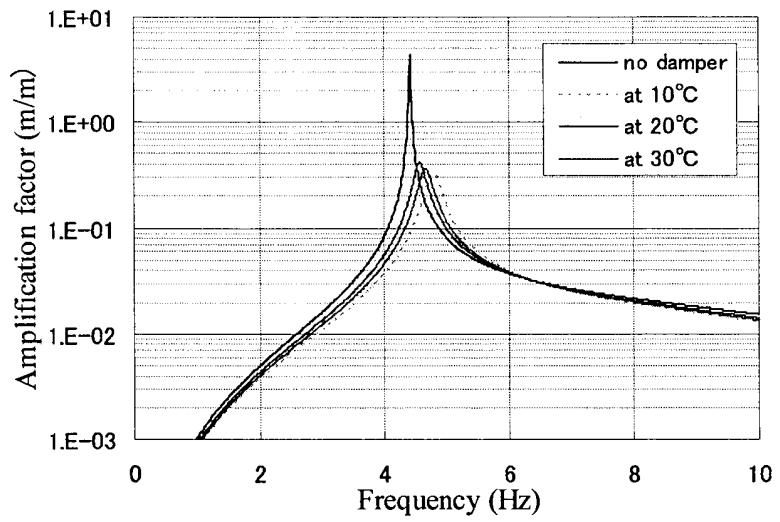

Fig.6 Amplification factor of longitudinal displacement between ends of damping device

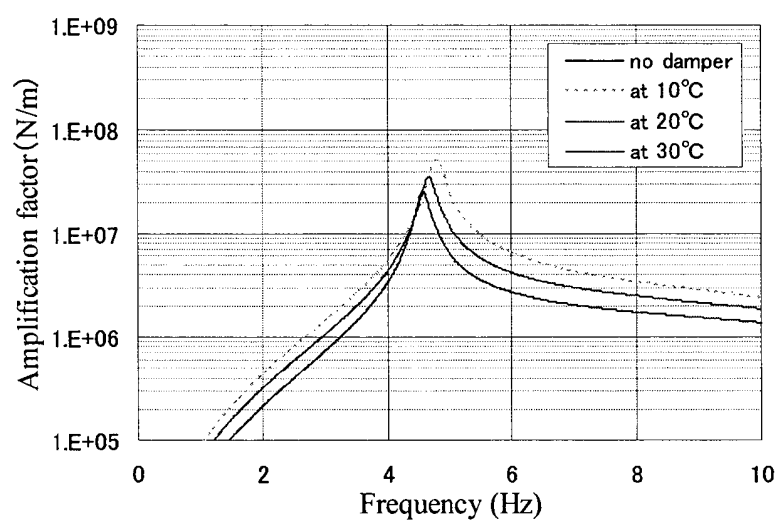

Fig.7 Amplification factor of applied force to damping device

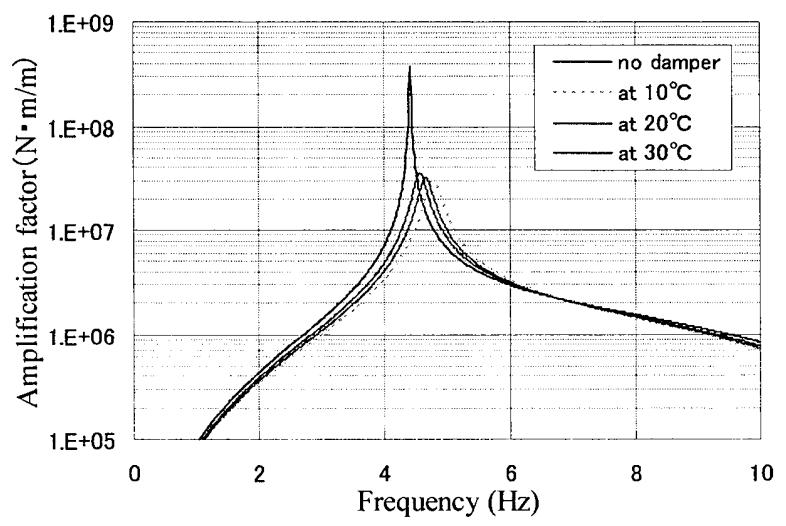

Fig.8 Amplification factor of bending moment at pole base
$3 \times 10^{5} \mathrm{Nm}$ （当該鋼管柱の許容モーメントにほぼ相当）である のに対して，制振器を取り付けた場合には $3 \times 10^{4} \mathrm{Nm}$ とほぼ $1 / 10$ に低減することがわかる.

\section{4. 実スケールモデルでの実装加振試験}

前章の特性解析に基づいて電柱制振器を試作し, 実スケ 一ルモデルでの実装加振試験を実施した。試験電柱は，鋼 管柱 $(\phi 355.6 \mathrm{~mm}$, 厚さ $6.4 \mathrm{~mm}$, 地際上長さ $9 \mathrm{~m})$ とし, 1 次 固有振動数は約 $4.4 \mathrm{~Hz}$ である.制振器は, 粘弾性体 $170 \times 1280$ $\times 1.6 \mathrm{~mm}$ を 3 層, 鋼板厚さ $4.5 \mathrm{~mm}$ の 4 枚構造, 全長 $1.7 \mathrm{~m}$ の制 振体を直交面に各 1 体, 計 2 体を取り付けた。試験方法は, 電柱先端を加振した際の自由振動波形から損失係数を算出 して評価した。

図 9 に試験状況を, 図10に電柱先端を加振した後の自由 振動加速度波形を示す。また図11に, 試験結果から得られ た加振方向別の損失係数を比較して示す。なお加振初期変 位はいずれも $10 \mathrm{~mm}$ 程度である。

損失係数は, 制振器のない場合の約 0.003 に対して, 制振 器を取り付けた場合は約 0.040 とおおよそ10倍に増加して おり, 制振器の制振効果が明瞭である.このことから, 地

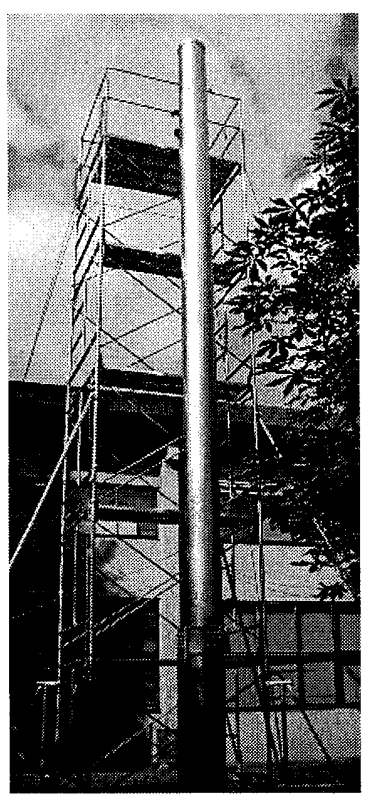

Test pole (steel-pipe pole)

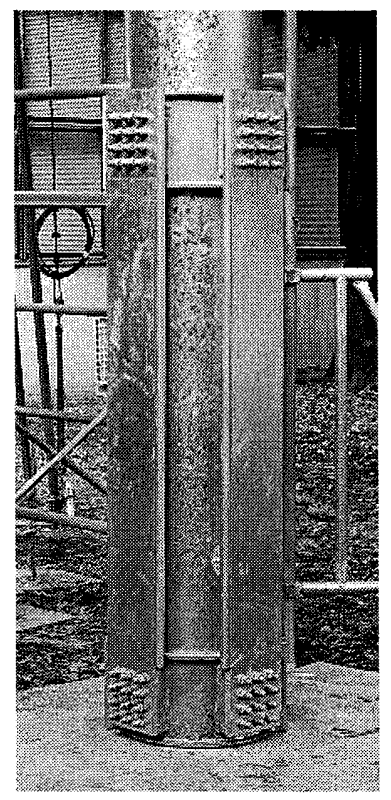

Damping device
Fig.9 Vibration test by real scale model

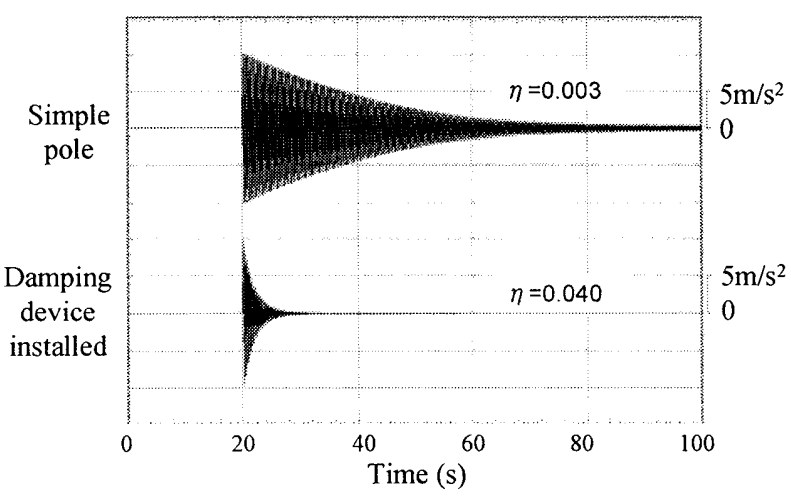

Fig.10 Comparison of pole-top acceleration waveform 


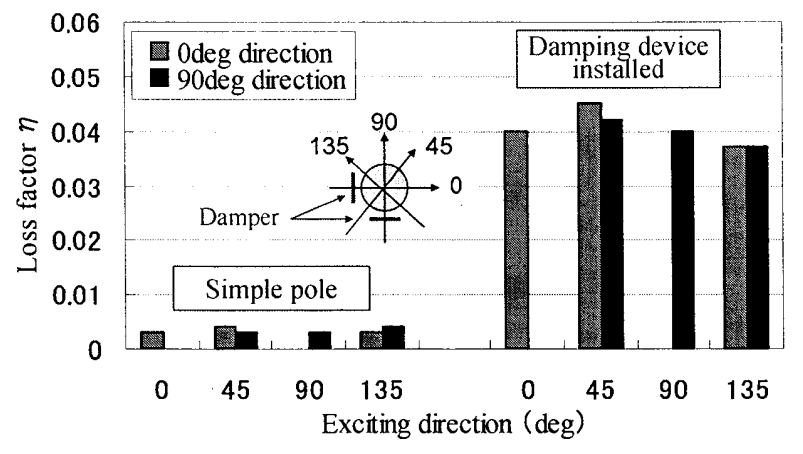

Fig.11 Comparison of loss factor in each direction

際加振時の先端応答倍率も約 $1 / 10$ に低減するものと期待 でき, 前章での解析結果とほぼ同様な結果が得られた。

制振器の取付方向に対して加振方向を変えても損失係数 はほぼ同じ值が得られた.このことから，制振体を直交し て配置することで電柱振動の全方向に対する制振効果が期 待できる。

\section{5. 加振台試験}

次に，振動加振台に実物電柱を設置し，電柱下部を加振 することによって,制振器の制振効果を確認した。電柱は, コンクリート柱 $10-40-\mathrm{N} 11 \mathrm{~B} （ \phi 400 \mathrm{~mm}$, 基礎上長さ $L=9 \mathrm{~m}$, $\left.\rho=208 \mathrm{~kg} / \mathrm{m}, E I=4.64 \times 10^{7} \mathrm{Nm}^{2}\right)$ とし， 1 本の電柱には制振 器を取り付けずに, もう一本の電柱に制振器を取り付けて これらを同時に加振して比較した。電柱基礎は高架橋での 実際の基礎を想定して $1 \mathrm{~m}$ 深さとし，モルタルを充填して 固定した. また電柱には, 架線重量に相当する $500 \mathrm{~kg}$ を基礎 上高さ6. $5 \mathrm{~m}$ の位置に取り付けた．制振体は前章での加振試 験と同じものを用いたが，加振方向に制振器を 2 体正対さ せて取り付けた。図12に，試験状況を示す。

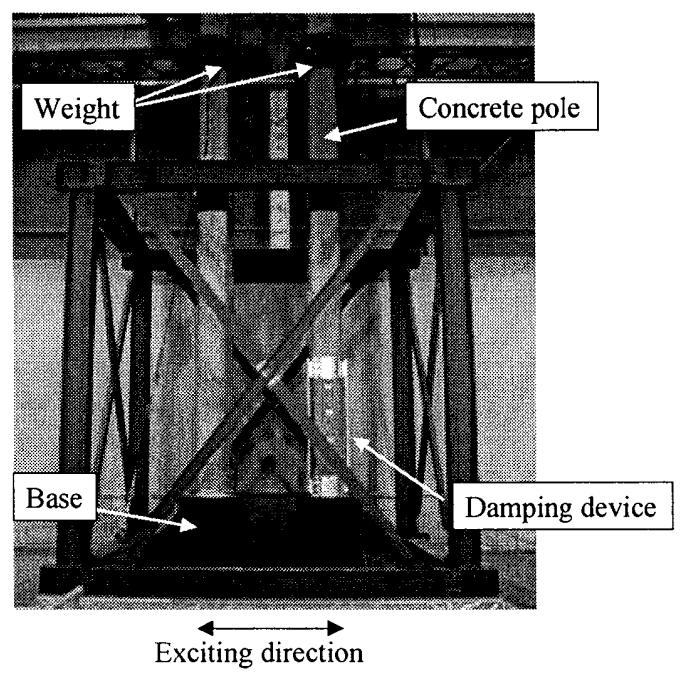

Fig.12 Vibration test at vibration table

図 13 K，試験結果の一例として，兵庫県南部地震の $1 / 10$ 振幅波形を入力した際の電柱地際のひずみ波形を示す。制 振器を取り付けた場合には，取り付けない場合に比べて最 大で約 $1 / 2$ に低減している. 図示していないが, 先端変位の 応答倍率も約 $1 / 2$ となっていることを確認している.ひずみ

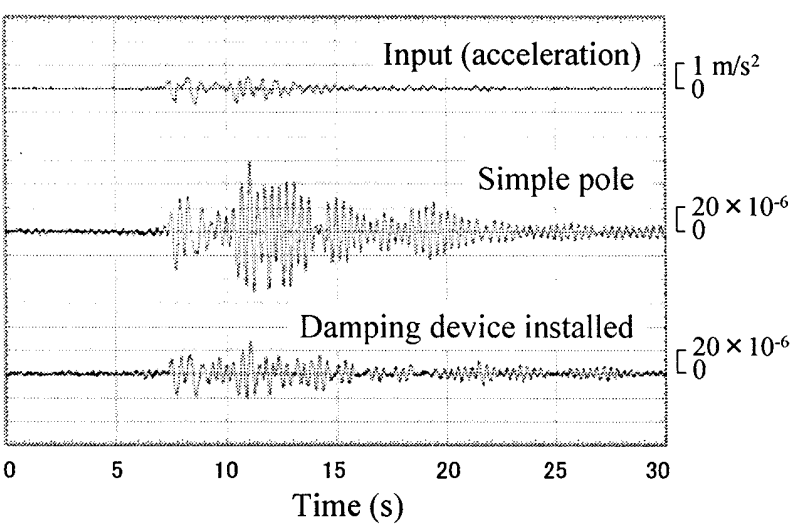

Fig.13 Comparison of bending strain at pole base

は曲げモーメントに比例するので，制振器を取り付けるこ とにより電柱の耐力も約 2 倍に増加すると考えられる.

なお，本試験における制振器の応答倍率低減効果は $1 / 2$ 程度であり，前章で示した鋼管柱の試験結果 $1 / 10$ 程度と比 ベて小さい。これは式(20)からわかるように，コンクリー 卜柱の質量が鋼管柱のそれに比べて大きいために，さらに 大きな減衰係数が必要なためと考えられる。.今後は, 電柱 種別に応じてさらに大きな減衰係数を有する制振器を試作 して性能確認を行うとともに，施工性，耐候性等を検証す るなどして実用化をめざしたい.

\section{6.まとめ}

粘弾性ダンパーによる電車線柱の制振方法を考案し, 梁 モデルによる電柱制振特性を解析するとともに，制振器を 試作して実スケール電柱を用いた実装加振試験を行った. これらをまとめると，以下のとおりである.

(1) 制振器は粘弾性体を鋼板で挟んで積層した構造とし,電 柱地際部に取り付けて電柱たわみ時の微小なせん断変形を 利用する制振方法である。

(2) 制振器の最適減衰値は, 電柱の機械インピーダンス, 長 さの二乗に比例する.

(3) 実スケールの制振器を試作し, 鋼管柱における実装加振 試験の結果, 損失係数が約 10 倍に増加することを確認した.

(4)制振体を直交して取り付けることにより,全方向に対し て制振効果があることを確認した。

(5)加振台において, 兵庫県南部地震波 (ただし振幅は $1 / 10$ ) で加振した結果，電柱地際の最大ひずみ（曲げモーメント） が約 $1 / 2$ に低減することを確認した.

\section{文献}

1) 電力設備耐震性調查研究委員会 : 電車線路設備耐震設計指針 (案)・同解説及びその適用例, 1997

2) 西 健太郎, 多胡正章, 大浦 泰, 藤井保和, 網干光雄 : 電車 線路設備の耐震性向上対策検討，JRAIL2008，2008

3)鈴木公一朗，池田国夫，関 忍，森田洋介：長野新幹線支持物 振動箇所におけるコネクタ振動特性等の研究, 平成 19 年電気学 会全国大会, 2007

4) 網干光雄, 大浦泰，五十幡直史，中村正治，砂子田勝昭，松岡 太一: 電柱制振器の基礎検討, 平成 20 年電気学会全国大会, 2008 